Louisiana State University

LSU Digital Commons

Faculty Publications

Department of Biological Sciences

$12-23-2015$

\title{
A Stable Coordination Complex of Rh(IV) in an N,O-Donor Environment
}

\author{
Shashi B. Sinha \\ Yale University \\ Dimitar Y. Shopov \\ Yale University \\ Liam S. Sharninghausen \\ Yale University \\ David J. Vinyard \\ Yale University \\ Brandon Q. Mercado \\ Yale University
}

See next page for additional authors

Follow this and additional works at: https://digitalcommons.Isu.edu/biosci_pubs

\section{Recommended Citation}

Sinha, S., Shopov, D., Sharninghausen, L., Vinyard, D., Mercado, B., Brudvig, G., \& Crabtree, R. (2015). A Stable Coordination Complex of Rh(IV) in an N,O-Donor Environment. Journal of the American Chemical Society, 137 (50), 15692-15695. https://doi.org/10.1021/jacs.5b12148

This Article is brought to you for free and open access by the Department of Biological Sciences at LSU Digital Commons. It has been accepted for inclusion in Faculty Publications by an authorized administrator of LSU Digital Commons. For more information, please contact ir@lsu.edu. 


\section{Authors}

Shashi B. Sinha, Dimitar Y. Shopov, Liam S. Sharninghausen, David J. Vinyard, Brandon Q. Mercado, Gary W. Brudvig, and Robert H. Crabtree 


\section{Communication}

\section{A Stable Coordination Complex of Rh(IV) in an $\mathrm{N}, \mathrm{O}$-donor Environment.}

Shashi B. Sinha, Dimitar Y. Shopov, Liam S Sharninghausen, David J.

Vinyard, Brandon Q. Mercado, Gary W. Brudvig, and Robert H. Crabtree

J. Am. Chem. Soc., Just Accepted Manuscript • DOI: 10.1021/jacs.5b12148 • Publication Date (Web): 07 Dec 2015

Downloaded from http://pubs.acs.org on December 9, 2015

\section{Just Accepted}

"Just Accepted" manuscripts have been peer-reviewed and accepted for publication. They are posted online prior to technical editing, formatting for publication and author proofing. The American Chemical Society provides "Just Accepted" as a free service to the research community to expedite the dissemination of scientific material as soon as possible after acceptance. "Just Accepted" manuscripts appear in full in PDF format accompanied by an HTML abstract. "Just Accepted" manuscripts have been fully peer reviewed, but should not be considered the official version of record. They are accessible to all readers and citable by the Digital Object Identifier (DOI $\left.{ }^{\circ}\right)$. "Just Accepted" is an optional service offered to authors. Therefore, the "Just Accepted" Web site may not include all articles that will be published in the journal. After a manuscript is technically edited and formatted, it will be removed from the "Just Accepted" Web site and published as an ASAP article. Note that technical editing may introduce minor changes to the manuscript text and/or graphics which could affect content, and all legal disclaimers and ethical guidelines that apply to the journal pertain. ACS cannot be held responsible for errors or consequences arising from the use of information contained in these "Just Accepted" manuscripts. 
Interest in high oxidation state transition metal complexes has grown considerably in recent years in connection with oxidation catalysis. ${ }^{1}$ While there are a number of well-established Ir(IV) complexes, the highest oxidation state commonly encountered for rhodium is $\mathrm{Rh}(\mathrm{III}){ }^{2,3}$ Among the very few $\mathrm{Rh}(\mathrm{IV})$ species known, $\left[\mathrm{RhX}_{6}\right]^{2-}(\mathrm{X}=\mathrm{Cl}$, F) are unstable in water, which has limited their characterization. ${ }^{4}$ There are also a number of poorly characterized solid-state $\mathrm{Rh}$ (IV) oxide species, ${ }^{5}$ as well as several formally $\mathrm{Rh}(\mathrm{IV})$ dinuclear organometallic compounds. ${ }^{6}$ Several other complexes, such as Claus' Blue, originally thought to feature $\mathrm{Rh}(\mathrm{IV})$, are in fact superoxides of $\mathrm{Rh}(\mathrm{III}){ }^{7} \quad \mathrm{Rh}(\mathrm{IV})$ species have been postulated as intermediates in chemical transformations, ${ }^{8}$ and characterization of a stable $\mathrm{Rh}$ (IV) complex is, therefore, of interest. However, there do not seem to be any examples of well characterized stable coordination compounds of $\mathrm{Rh}$ (IV) with organic ligands; a few reports of metastable $\mathrm{Rh}(\mathrm{IV})$ species present only very limited characterization. ${ }^{9}$ A common problem with these and other highly oxidized complexes is oxidative instability of the organic ligands, which limits the formation of stable species. ${ }^{10}$

We recently reported that the oxidatively robust, bidentate pyridinealkoxide ligand pyalk (2-(2-pyridyl)-2-propanoate) strongly stabilizes high oxidation states. ${ }^{3}$ Both the facial and meridional isomers of $\operatorname{Ir}(\text { pyalk })_{3}{ }^{0 /+}$ had easily accessible III/IV couples, with the meridional isomer having what may be the lowest $\mathrm{Ir}^{\mathrm{III} / \mathrm{IV}}$ reduction potential ever reported. In water-oxidation catalysis, ${ }^{11}$ pyalk displays extremely high stability even under harsh catalytic conditions. We now report an extension of these observations to the stabilization of the more challenging $\mathrm{Rh}(\mathrm{IV})$ oxidation state. The meridional $\left(\mathbf{1}^{\mathrm{II}}\right)$ and facial $\left(2^{\mathrm{II}}\right)$ isomers of $\left[\mathrm{Rh}^{\mathrm{III}}(\text { pyalk) })_{3}\right]$ (Scheme 1) can be synthesized, separated and characterized. The mer isomer shows a reversible electrochemical redox couple, and can be cleanly chemically oxidized to the corresponding $\left[\mathrm{Rh}^{\mathrm{IV}}(\text { pyalk })_{3}\right]^{+}$species, which proves to be kinetically stable in a range of solvents including water. Full

characterization, including the first clear and well-simulated $\mathrm{Rh}$ (IV) EPR spectrum as well as the first crystal structure of a $\mathrm{Rh}$ (IV) coordination complex with organic ligands, establishes the identity of this complex.

Scheme 1. Preparation of complexes $1^{\mathrm{II}}, 2^{\mathrm{III}}$ and $\left[1^{\mathrm{IV}}\right] \mathrm{SbF}_{6}$.
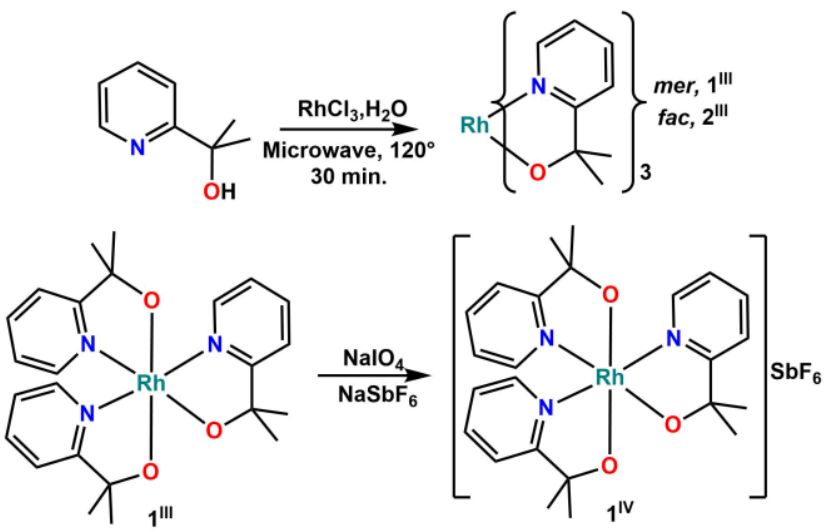

Compounds $1^{\mathrm{III}}$ and $2^{\mathrm{III}}$ were prepared by microwave heating an aqueous solution of $\mathrm{RhCl}_{3}$ with an excess of Hpyalk (Scheme 1). With excess ligand as the base, clean conversion occurs without formation of metal oxides. Separation of $\mathbf{1}^{\mathrm{II}}$ and $\mathbf{2}^{\mathrm{II}}$ is possible due to their disparate polarities (see SI). Both $\mathbf{1}^{\text {III }}$ and $2^{\text {III }}$ were isolated as air-stable yellow powders exhibiting a remarkably broad solubility range and were fully characterized. $1^{\mathrm{III}}$ is the major product of the reaction ( $9: 1$ ratio $v s 2^{\mathrm{II}}$ based on ${ }^{1} \mathrm{H}$ NMR of the crude mixture; $60 \%$ isolated yield), while $2^{\mathrm{III}}$ is the minor product (2\% isolated yield). The complexes display the ${ }^{1} \mathrm{H}$ and ${ }^{13} \mathrm{C}$ NMR signals (See SI, Page S5) expected from their symmetry, with three sets of ligand signals for $1^{\mathrm{III}}$ and only one for $2^{\mathrm{III}}$. The methyl groups of the ligands are inequivalent in both ${ }^{1} \mathrm{H}$ and ${ }^{13} \mathrm{C} \mathrm{NMR}$, as expected.

Addition of sodium periodate to a solution of $1^{\text {III }}$ causes a color change from pale yellow to dark purple over approximately 20 minutes. This new species can be extracted into dichloromethane and crystallized, after addition of $\mathrm{SbF}_{6}$, to give $\left[1^{\mathrm{IV}}\right] \mathrm{SbF}_{6}$ as a dark violet solid. This rare $\mathrm{Rh}$ (IV) complex shows much greater stability in both aqueous and oxidation-resistant organic solvents than previous $\mathrm{Rh}$ (IV) coordination compounds. ${ }^{9}$ At room temperature, degradation proceeds over the course of several days and primarily involves the reversible reduction to $1^{\mathrm{III}}$, a process also achieved with chemical reductants like sodium ascorbate. In contrast, attempts to oxidize $2^{\mathrm{III}}$ did not result in 
an isolable species. This difference in redox properties is consistent with our findings for the Ir analogues.
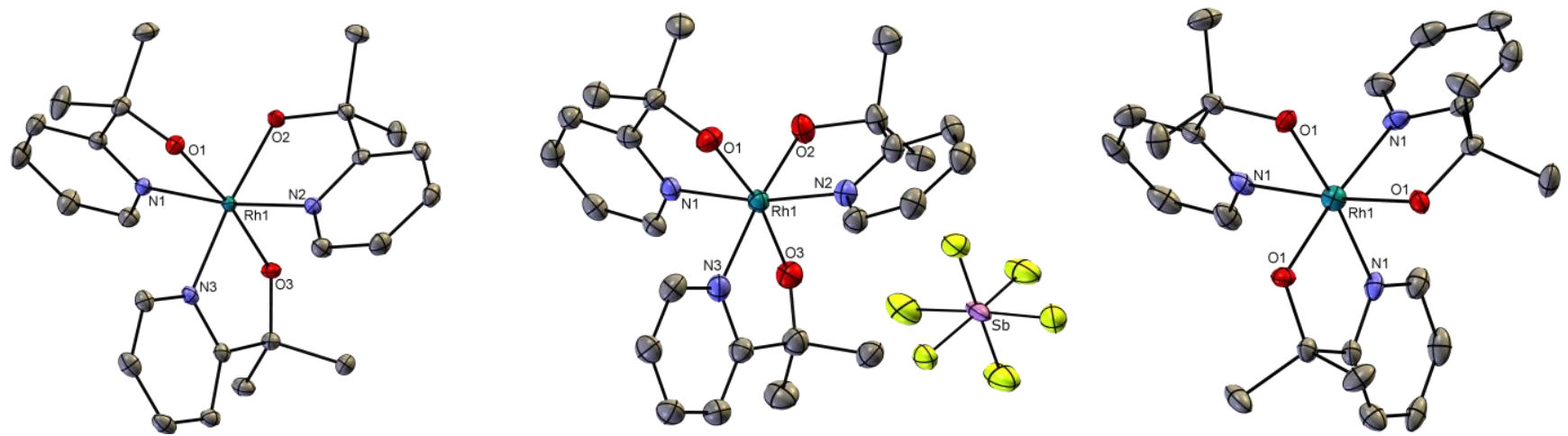

Figure 1 . Thermal ellipsoid diagrams of the crystal structures of $\mathbf{1}^{\mathrm{II}}$ (left, at $50 \%$ probability level), [ $\left.\mathbf{1}^{\mathrm{IV}}\right] \mathrm{SbF}_{6}$ (center) and $\mathbf{2}^{\mathrm{III}}$ (left) at $30 \%$ probability level. Hydrogen atoms have been omitted for clarity.

Crystal structures were obtained for $\mathbf{1}^{\mathrm{III}},\left[\mathbf{1}^{\mathrm{IV}}\right] \mathrm{SbF}_{6}$ and $2^{\mathrm{III}}$ (Figure 1 ). The Rh-O bonds contract noticeably (by ca. $0.08 \AA$ on average) upon oxidation (Table 1), consistent with a metal-centered process, while the $\mathrm{Rh}-\mathrm{N}$ bonds undergo a slight extension, trends that are in line with the analogous Ir complexes. ${ }^{3}$ To our knowledge, the structure of $\left[\mathbf{1}^{\mathrm{IV}}\right] \mathrm{SbF}_{6}$ represents the first example of a crystal structure of a molecular Rh(IV) coordination complex with organic ligands. Complex $\mathbf{1}^{\mathrm{II}}$ crystallizes as a well-ordered monohydrate. Complex $2^{\mathrm{III}}$, demonstrates high cation affinity by coordinating to $\mathrm{Na}^{+}$ions with its facial alkoxide groups; chloride counterions and disordered dichloromethane molecules are also present (See SI).

Table 1. Comparison of selected crystallographic bond distances in $1^{\mathrm{III}}$ and $\left[1^{\mathrm{IV}}\right] \mathrm{SbF}_{6}$.

\begin{tabular}{lll}
\hline Bond & $\mathbf{1}^{\mathrm{II}}$ & {$\left[\mathbf{1}^{\mathrm{I}}\right] \mathrm{SbF}_{6}{ }^{\mathrm{a}}$} \\
\hline Rh1-N1 & $2.019(1)$ & $2.025(5)$ \\
Rh1-N2 & $2.015(1)$ & $2.027(6)$ \\
Rh1-N3 & $2.029(1)$ & $2.063(5)$ \\
Rh1-O1 & $2.022(1)$ & $1.920(5)$ \\
Rh1-O2 & $1.990(1)$ & $1.923(6)$ \\
Rh1-O3 & $2.044(1)$ & $1.965(5)$
\end{tabular}

${ }^{\mathrm{a}}$ Bond lengths calculated as average of lengths in the two molecules in the asymmetric unit.

While the UV-visible spectrum (Figure 2) of $\mathbf{1}^{\text {III }}$ only shows a weak absorption tail in the visible region, the oxidized state shows three peaks, the strongest at $520 \mathrm{~nm}$ having $\varepsilon=2500 \mathrm{M}^{-1} \mathrm{~cm}^{-1}$. These peaks are assigned to ligand-to-metal charge transfers by analogy with $\operatorname{Ir}(\mathrm{IV})$ species; the $\mathrm{Rh}(\mathrm{IV})$ spectrum closely resembles the Ir analog's, but is red-shifted by approximately $100-150 \mathrm{~nm} .^{3}$

Electron paramagnetic resonance spectroscopy on $\mathbf{1}^{\mathrm{IV}}$ (Figure 3 ) provides further evidence for the $\mathrm{Rh}(\mathrm{IV})$ state. Consistent with the proposed $S=1 / 2$ system, a rhombic signal is evident which displays hyperfine coupling to ${ }^{103} \mathrm{Rh}(\mathrm{I}=1 / 2)$, resolved as doublets in the mid-field and high-field peaks. The magnitude of the ${ }^{103} \mathrm{Rh}$ hyperfine coupling and the breadth of the signal are strongly indicative of a metal-centered electron spin. Coupling to ${ }^{14} \mathrm{~N}$ is not observed, consistent with calculations on the analogous Ir complex that showed essentially no frontier orbital occupancy on N. ${ }^{3}$ The spectrum was successfully simulated by considering only the ${ }^{103} \mathrm{Rh}$ coupling and diffuse hyperfine strain (Figure 3). This seems to be the first example of a clean, solutionphase Rh(IV) EPR spectrum for which Rh coupling is resolved.

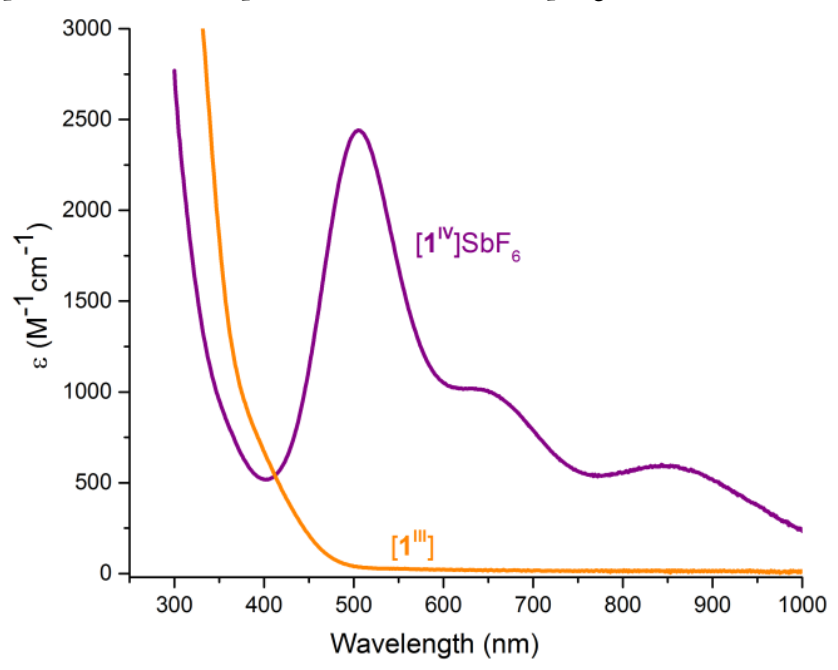

Figure 2. UV-visible absorption spectra of $\left[1^{\mathrm{III}}\right]$ (orange) and $\left[\mathbf{1}^{\mathrm{IV}}\right] \mathrm{SbF}_{6}$ (purple) in dichloromethane.

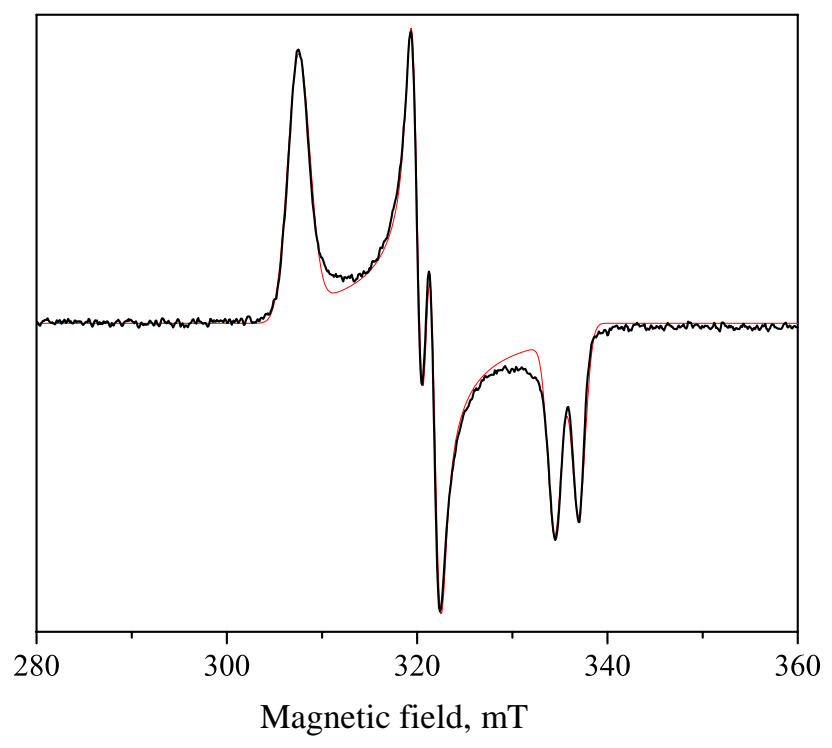

Figure 3. X-band EPR spectrum of compound $1^{\mathrm{IV}}$ measured at $8 \mathrm{~K}$ 
(black) and simulation (red). Compound $\mathbf{1}^{\mathrm{IV}}$ has a rhombic EPR spectrum with $g=[2.180,2.089,1.997]$ consistent with low-spin $(\mathrm{S}=$ $1 / 2) \mathrm{Rh}(\mathrm{IV})$. Hyperfine interactions from the $\mathrm{I}=1 / 2{ }^{103} \mathrm{Rh}$ nucleus $(100 \%)$ were simulated using principal values of 31,53 , and $70 \mathrm{MHz}$. Anisotropic line broadening was simulated using the $\mathrm{H}$-strain tensor $[70,33,44] \mathrm{MHz}$ to account for unresolved hyperfine interactions.

In cyclic voltammetry, each isomer shows only one redox feature in the range studied, but at significantly different potentials. For 1, a fully reversible feature at $0.98 \mathrm{~V}$ vs. NHE ( $\mathrm{pH} \mathrm{7,} \mathrm{phosphate} \mathrm{buffer)} \mathrm{is}$ observed with cathodic and anodic currents essentially equal at all scan rates (Figure 4) and with the expected square-root relationship between peak current and scan rate. The symmetry between anodic and cathodic waves supports the reversible nature of this feature, which we assign as the $\mathrm{Rh}^{\mathrm{III} / \mathrm{IV}}$ couple. While there is a noticeable rise in the peak-to-peak separation at higher scan rates, this is likely due to slow electron transfer at the working electrode, boron-doped diamond (BDD). Although $\mathrm{BDD}$ is known to have substantially slower electron transfer kinetics than more common electrodes, ${ }^{12}$ it is better adapted for aqueous work at these high potentials, having much lower background current. In contrast to $\mathbf{1}$, the redox feature for $\mathbf{2}$ is only quasi-reversible (See SI, Page S9). Due to its very high potential ( $1.38 \mathrm{~V}$ vs. NHE), as well as an underlying catalytic wave (presumably degradation), the oxidized state is most likely short-lived under these conditions. While no characterization has been attempted so far, we tentatively attribute this feature to a $\mathrm{Rh}^{\mathrm{III} / \mathrm{IV}}$ couple as well.

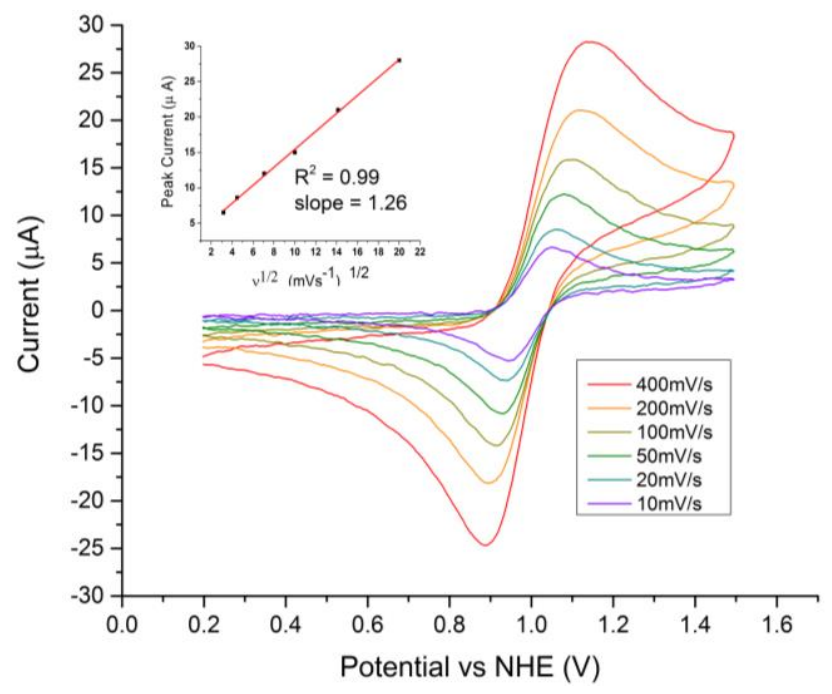

Figure 4. Cyclic voltammograms of 1 in $0.1 \mathrm{M}$ phosphate buffer at $\mathrm{pH}$ 7.0 at different scan rates from $10 \mathrm{mV} \mathrm{s}^{-1}$ to $400 \mathrm{mV} \mathrm{s}^{-1}$. Insert: plot of peak current versus (scan rate $)^{1 / 2}$.

The $\mathrm{Rh}^{\mathrm{III} / \mathrm{IV}}$ couples are $\mathrm{pH}$ dependent, suggesting that the alkoxide groups in the $\mathrm{Rh}(\mathrm{III})$ state are sufficiently basic to be partially protonated even at neutral $\mathrm{pH}$. The Pourbaix curve for the $\mathrm{Rh}^{\mathrm{III} / \mathrm{IV}}$ couple of 1 (Figure 5) indicates a proton-dependent $\left(1 \mathrm{H}^{+} / \mathrm{e}^{-}\right)$electrontransfer regime below $\mathrm{pH} 7$ and a proton-independent regime above $\mathrm{pH}$ 8 . Based on the basicity of the alkoxide, we assign the $\mathrm{Rh}$ (III) species in acid as monoprotonated $\left[1^{\mathrm{II}} \mathrm{H}\right]^{+}$, in base as $\mathbf{1}^{\mathrm{III}}$, and in the oxidized state as the $\mathrm{pH}$-invariant $\left[\mathbf{1}^{\mathrm{IV}}\right]^{+}$. Because basic conditions provide a stable regime involving two well-defined species, we can compare the aqueous $\mathrm{Rh}^{\mathrm{III} / \mathrm{IV}}$ potential for $1^{\mathrm{III}}$ at $0.935 \mathrm{~V}$ vs. NHE with that for $2^{\mathrm{III}}$ with $\mathrm{E}_{1 / 2}=$ $1.28 \mathrm{~V}$ at $\mathrm{pH} 11$, their separation being $0.345 \mathrm{~V}$. We will use these as the formal aqueous $\mathrm{Rh}^{\mathrm{III} / \mathrm{IV}}$ potentials. Both the mer/fac isomer separation and the features of the Pourbaix curve very closely mirror those for the $\operatorname{Ir}$ (pyalk) ${ }_{3}$ complexes, ${ }^{3}$ the primary difference being the $\mathrm{Rh} / \mathrm{Ir}$ offset, of ca. $0.5 \mathrm{~V}$. The lack of perfect linearity in the $\mathrm{pH}=3-7$ range is attributed to the highly basic character of the alkoxide ligands that promotes $\mathrm{pH}$ - dependent hydrogen bonding and ion binding, as also observed for the Ir analog. ${ }^{3}$

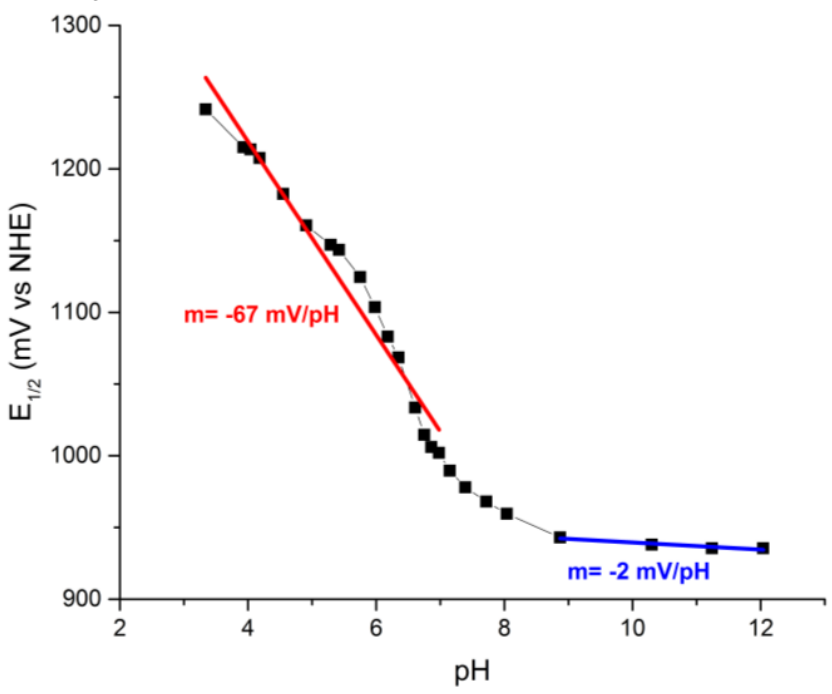

Figure 5. $\mathrm{pH}$ dependence of the $\mathrm{Rh}^{\mathrm{III} / \mathrm{IV}}$ electrochemical redox couple for 1. Linear regression fits and their slopes are given for data points $\mathrm{pH}<7$ (red) and $\mathrm{pH}>8$ (blue).

The reasons our mer complex avoids the typical instability of the $\mathrm{Rh}(\mathrm{IV})$ state are the strong donor and oxidation-resistant tertiary alkoxide ligands, as well as the meridional geometry itself. For iridium, alkoxides can be extremely potent donors, surpassing even phenyl ligands $;^{3,13}$ this has been ascribed to their dual $\sigma$ - and $\pi$-donating character. Furthermore, we and others ${ }^{3,11}$ have shown the importance of ligand orientation on redox properties. The ease of oxidation depends not only on the sum of the donor effects of the ligand groups, following Lever, ${ }^{14}$ but also on the electronic splitting of the otherwise degenerate $\mathrm{t}_{2 \mathrm{~g}} d$-orbitals. A $\mathrm{d}^{6} \rightarrow \mathrm{d}^{5}$ oxidation of a pseudo octahedral complex is facilitated when one orbital energy is raised via this splitting. Because the $t_{2 g}$ orbitals are planar in shape, the greatest effect occurs when the most electron-donating ligands all lie in one plane. In our case, all three alkoxides occupy one plane in the mer complex 1, whereas for the symmetric fac complex 2, all planes, and thus all $\mathrm{t}_{2 \mathrm{~g}}$ orbitals, are equivalent. The net result is that 1 experiences this anisotropic oxidation enhancement effect that splits the $t_{2 g} d$-orbitals, while 2 does not. Although the magnitude of the effect is essentially the same for $\mathrm{Rh}$ and $\mathrm{Ir}$, the practical implications for $\mathrm{Rh}$ (pyalk) $)_{3}$ are far more impressive: one isomer $\left(\mathbf{1}^{\mathrm{II}}\right)$ forms an unprecedentedly stable and long-lived $\mathrm{Rh}$ (IV) species, while the other $\left(2^{\mathrm{II}}\right)$ forms one only transiently.

In conclusion, we have prepared and characterized mer$\left[\mathrm{Rh}^{\mathrm{III}}(\text { pyalk })_{3}\right]$, a rhodium coordination complex capable of accessing the rare $\mathrm{Rh}(\mathrm{IV})$ oxidation state through both chemical and electrochemical oxidation. In contrast to the previously known $\mathrm{Rh}$ (IV) coordination complexes, mer- $\left[\mathrm{Rh}^{\mathrm{IV}}(\text { pyalk })_{3}\right]$ is stable for long periods in a range of solvents. This facilitates characterization by several methods including unprecedented X-ray crystallography and EPR spectroscopy for the $\mathrm{Rh}$ (IV) state. The remarkable stability of this complex arises from the strongly donating ligand set, the oxidation-resistant nature of the ligand and the meridional ligand arrangement. The importance of this last aspect is illustrated by the inability of the compositionally equivalent facial isomer, fac- $\left[\mathrm{Rh}^{\mathrm{III}}(\text { pyalk })_{3}\right]$, to form a stable $\mathrm{Rh}(\mathrm{IV})$ state, showing that coordination geometry can be a critical factor in oxidation state stability.

\section{ASSOCIATED CONTENT}

\section{Supporting Information}


Crystal structure files, additional figures, as well as detailed synthetic procedures and physical methods are available free of charge via the Internet at http://pubs.acs.org.

\section{AUTHOR INFORMATION}

\section{Corresponding Authors}

robert.crabtree@yale.edu and gary.brudvig@yale.edu

\section{Author Contributions \\ ${ }^{\dagger}$ These authors contributed equally.}

\section{Notes}

The authors declare no competing financial interest.

\section{ACKNOWLEDGMENT}

This work was supported the U.S. Department of Energy, Office of Science, Office of Basic Energy Sciences, Division of Chemical Sciences, Geosciences, and Biosciences under Award Number DE-SC0001059 as part of the Argonne-Northwestern Solar Energy Research (ANSER) Energy Frontier Research Center (spectroscopy and characterization) and under Award Number DEFG02-07ER15909 (synthesis).

\section{REFERENCES}

(1) (a) Wang, G. J.; Zhou, M. F.; Goettel, J. T.; Schrobilgen, G. J.; Su, J.; Li, J.; Schloder, T.; Riedel, S. Nature 2014, 514, 475. (b) Sinha, W.; Sommer, M. G.; Deibel, N.; Ehret, F.; Bauer, M.; Sarkar, B.; Kar, S. Angew. Chem. Int. Ed. 2015, 54, 13769. (c) Sheldon, R. A.; Kochi, J. K. Metal-Catalyzed Oxidations of Organic Compounds: Mechanistic Principles and Synthetic Methodology Including Biochemical Processes; Academic Press: New York, NY, 1981. (d) Jørgensen, C. K. Oxidation numbers and Oxidation States; Springer: Heidelberg, Germany, 1969. (e) Donoghue, P. J.; Tehranchi, J.; Cramer, C. J.; Sarangi, R.; Solomon, E. I.; Tolman, W. B. J. Am. Chem. Soc. 2011, 133, 17602. (f) Topczewski, J. J.; Sanford, M. S. Chem. Sci. 2015, 6, 70.

(2) (a) Gulliver, D. J.; Levason, W. Coord. Chem. Rev. 1982, 46, 1. (b) Jardine, F. H. Rhodium: Inorganic \& Coordination Chemistry; John Wiley \& Sons Ltd.: Hoboken, NJ, 2006. (c) Campos, J.; Esqueda, A. C.; Lopez-Serrano, J.; Sanchez, L.; Cossio, F. P.; de Cozar, A.; Alvarez, E.; Maya, C.; Carmona, E. J.
Am. Chem. Soc. 2010, 132, 16765. (d) Sewell, L. J.; Lloyd-Jones, G. C.; Weller, A. S. J. Am. Chem. Soc. 2012, 134, 3598.

(3) Shopov, D. Y.; Rudshteyn, B.; Campos, J.; Batista, V. S.; Crabtree, R. H.; Brudvig, G. W. J. Am. Chem. Soc. 2015, 137,7243.

(4) (a) Wilhelm, V.; Hoppe, R. Z. Anorg. Allg. Chem. 1974, 407, 13. (b) Ellison, I. J.; Gillard, R. D. Polyhedron 1996, 15, 339.

(5) (a) Bayer, G.; Wiedemann, H. G. Thermochim. Acta 1974, 15, 213. (b) Muller, O.; Rustum, R. J. Less Common Met. 1968, 16, 129. (c) Shannon, R. D. Solid State Commun. 1968, 6, 139. (d) Vente, J. F.; Lear, J. K.; Battle, P. D. J. Mater. Chem. 1995, 5, 1785.

(6) (a) Meanwell, N. J.; Smith, A. J.; Maitlis, P. M. J. Chem. Soc., Dalton Trans. 1986, 1419. (b) Wang, Z. Q.; Turner, M. L.; Taylor, B. F.; Maitlis, P. M. Polyhedron 1995, 14, 2767. (c) Osakada, K.; Koizumi, T.; Yamamoto, T. Bull. Chem. Soc.Jpn. 1997, 70, 189. (d) Isobe, K.; Okeya, S.; Meanwell, N. J.; Smith, A. J.; Adams, H.; Maitlis, P. M. J. Chem. Soc., Dalton Trans. 1984, 1215.

(7) (a) Ellison, I. J.; Gillard, R. D. J. Chem. Soc., Chem. Commun. 1992, 851. (b) Edwards, N. S. A.; Ellison, I. J.; Gillard, R. D.; Mile, B.; Maher, J. Polyhedron 1993, 12, 371 .

(8) (a) Pestovsky, O.; Bakac, A. Inorg. Chem. 2002, 41, 3975. (b) Pestovsky, O.; Bakac, A. Inorg. Chem. 2002, 41, 901. (c) Pestovsky, O.; Bakac, A. J. Am. Chem. Soc. 2002, 124, 1698. (d) Kim, M. Y.; Seok, W. K.; Dong, Y.; Yun, H. Inorg. Chim. Acta 2001, 319, 194.

(9) (a) Basu, S.; Peng, S-M.; Lee, G-H.; Bhattacharya, S. Polyhedron 2005, 24, 157. (b) Lee, W-T. PhD. Thesis, University of Iowa, Iowa City, IA, 2011. (c) Bond, A. M.; Colton, R.; Mann, D. R. Inorg. Chem. 1990, 29, 4665.

(10) (a) Crabtree, R. H. J. Organomet. Chem. 2014, 751, 174. (b) Kotani, H.; Sugiyama, T.; Ishizuka, T.; Shiota, Y.; Yoshizawa, K.; Kojima, T. J. Am. Chem. Soc. 2015, 137, 11222.

(11) (a) Schley, N. D.; Blakemore, J. D.; Subbaiyan, N. K.; Incarvito, C. D.; D'Souza, F.; Crabtree, R. H.; Brudvig, G. W. J.Am. Chem. Soc., 2011, 133, 10473. (b) Hintermair, U.; Hashmi, S. M.; Elimelech, M.; Crabtree, R. H. J. Am. Chem. Soc., 2012, 134, 9785. (c) Hintermair, U.; Sheehan, S. W.; Parent, A. R.; Ess, D. H.; Richens, D. T.; Vaccaro, P. H.; Brudvig, G. W.; Crabtree, R. H. J. Am. Chem. Soc. 2013, 135, 10837. (d) Thomsen, J. M.; Sheehan, S. W.; Hashmi, S. M.; Campos, J.; Hintermair, U.; Crabtree, R. H.; Brudvig, G. W. J. Am. Chem. Soc. 2014, 136, 13826. (e) Sheehan, S. W.; Thomsen, J. M.; Hintermair, U.; Crabtree, R. H.; Brudvig, G. W.; Schmuttenmaer, C. A. Nat. Commun. 2015, 6,6469 .

(12) Bano, K.; Zhang, J.; Bond, A. M.; Unwin, P. R.; Macpherson, J. V. J. Phys. Chem. C. 2015, 19, 12464.

(13) Tamayo, A. B.; Alleyne, B. D.; Djurovich, P. I.; Lamansky, S.;Tsyba, I.; Ho, N. N.; Bau, R.; Thompson, M. E. J. Am. Chem. Soc. 2003, 125, 7377.

(14) Lever, A. B. P. Inorg. Chem. 1990, 29, 1271. 
1

2

3

4

5

6

7

8

9

10

11

12

13

14

15

16

17

18

19

20

21

22

23

24

25

26

27

28

29

30

31

32

33

34

35

36

37

38

39

40

41

42

43

44

45

46

47

48

49

50

51

52

53

54

55

56

57

58

59

60

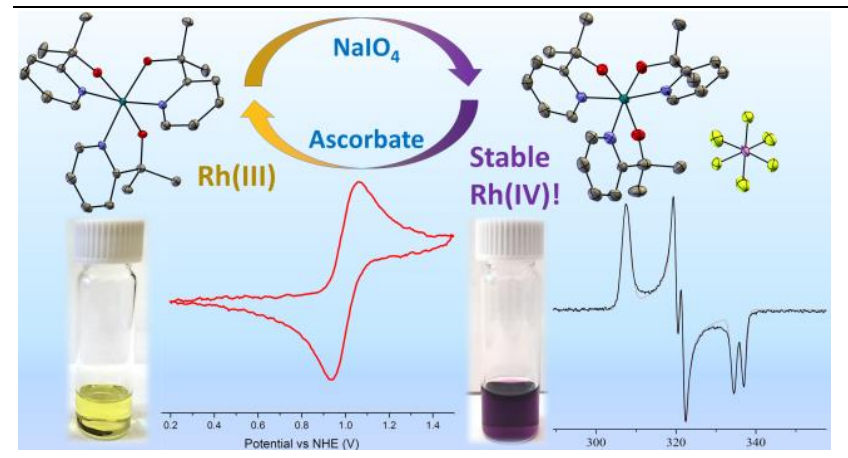

Insert Table of Contents artwork here 